\title{
"Promoting Cities as Places of Promise": Remarks at the Annual Meeting of the Coalition of Urban and Metropolitan Universities \\ Washington, D.C., October 23, 2016
}

\author{
Blair A. Ruble
}

At the height of the Cold War, Soviet wags loved to tell ironic tales about their political leaders. Communist Party general secretary Leonid Brezhnev inspired a number of particularly endearing stories, which always somehow related to his being slightly at sea in the middle of the world events swirling around him. One such anikdot pitted the witless Brezhnev against a wily Richard Nixon.

Brezhnev and Nixon, it seems, were meeting in the White House when the American president decided to call God for advice. He summoned an aide, who brought a large white phone. A few moments after he had completed his consultation with the Divine Being, another assistant came in with a receipt. Nixon approved the bill of some $\$ 20$ million for the call.

Flying back to Moscow, a furious Brezhnev inquired of the cowering Red Army officers how it was that the Americans could call God but he could not. He demanded that the entire Soviet military research complex dedicate itself to establishing phone service with God.

A few months later, it was time for Nixon to visit Moscow. The two leaders sat in Brezhnev's Kremlin office. At a critical juncture in the negotiations, Brezhnev summoned an aide, who brought a red phone that was even bigger than the white one Nixon had used in the Oval Office. Brezhnev dialed a number and had a brief conversation. A few moments later, an obsequious aide shuffled into the meeting with a receipt for just 2 kopecks (or 0.02 ruble).

Brezhnev was pleased, but perplexed. Why, he asked his assistant, once the Americans had departed, had it cost Nixon \$20 million to place his call, but he, the Communist general secretary, had to pay only 2 kopecks? The subordinate quickly responded, "Because calling the Devil from Moscow is only a local call."

Paradoxically, this very Moscow where Hell was just a local call away also happened to be one of the planet's most creative cities. Internationally acclaimed authors were penning their best works; noble ballerinas were training; world-class actors were perfecting their craft; some of the world's best mathematicians were arguing over equations. People with vast differences came and went every day jostling one another on streets that, indeed, resembled visions of Dante's Inferno at times.

Moscow under Brezhnev underscored the reality that creativity does not necessarily coexist with virtue. But with what does creativity co-exist? 
Whatever else Brezhnev's Moscow was, many Muscovites of the time believed it to be a place of promise. Many of my friends arrived in Moscow from lonely provincial towns scattered across a dozen time zones. For them, Moscow was all about promise.

Living in and traveling to Brezhnev's Moscow forced me to ponder the apparent contradiction between the gray and repressed existence of everyday life in the Soviet Union and the bright and impressive personalities who seemed to abound. I often have found myself drawn back to that vision of my Moscow friends at the time that their bedraggled city was a place of promise.

What does it mean for a city to be a place of promise? One lesson from Soviet-era Moscow is that we have to explore many different dimensions of urban life to answer that question. Indeed, today - literally today, a Sunday in October 2016 - turns out to be a propitious moment for advancing holistic concepts of the city as places of promise.

In trying to explore the notion of the city as a place of promise, let me begin with place. When we think any particular place, be it a metropolitan region, a city, a neighborhood, a university campus, or a rural town, there really is only one question that matters: Would parents want their children to be here, in this place?

Think about it; such a simple question; a simple question requiring the most complex of answers. Yet, this is a question that is so essential for thinking about how universities, cities, and metropolitan regions fit together.

I would like to step back and offer a couple of very brief reflections about these connections by looking to the global context of your work. And when I say global, I mean global in the sense of the planet. I want to do so today in particular because this is an exciting moment for all of us who think about cities.

Just last Thursday, the United Nations concluded an important summit on cities that will shape much of what happens in, to, and with cities in the years ahead. That meeting in Quito, Ecuador marks the culmination of a multi-year UN process that includes the approval of an "urban" sustainable development goal by the General Assembly in 2015, and the adoption just a few days ago by all member states, including the United States, of a New Urban Agenda. What this means is that the United States Government has just acknowledged an inclusive agenda for urban resilience as an international obligation.

As I just noted, the United Nations convened HABITAT III earlier this week, as the next in a series of UN convocations examining human habitat which have been scheduled to take place every two decades. HABITAT I was held in Vancouver in 1976; HABITAT II, in Istanbul in 1996; while HABITAT III just came to an end earlier this week. One of the lessons to emerge from HABITAT I and II is that the state-to-state resolutions endorsed at those convocations largely fell out of view almost immediately following the fall of the last gavel. This time around the UN decided to pursue a more lasting impact. The United States Government was among the most outspoken UN members advocating for action as well as words. 
This process was aided by the simultaneous - yet distinct - process of establishing post-2015 Sustainable Development Goals to follow on the Millennial Development Goals adopted by the UN in 2000. The New Urban Agenda just adopted by UN members is intended to advance the objectives of Sustainable Development Goal \# 11, which exhorts member states to "Make Cities Inclusive, Safe, Resilient, and Sustainable." In other words, make cities the sorts of places of opportunity where parents will want their children to be.

More particularly, I want to highlight four dimensions of the New Urban Agenda that, to me, go to the heart of what you are about; namely their focus on: inclusive cities, safer cities, governance, economic development.

On inclusive cities, while urbanization can provide potential for greater social inclusion, too often this is not the case. Inequality and exclusion abound often at greater rates than the national averages. To combat the rise of urban exclusion there has to be: (a) a political commitment to inclusive development, and (b) a range of mechanisms to facilitate inclusion, including participatory policy making and enhanced transparency and accountability. You all can make a positive difference in how we move forward to make cities more inclusive.

On safer cities, enhanced citizen security, be it crime prevention, protection from terrorism, or unsafe conditions, is highly dependent on all levels of government playing a leadership role. Citizen empowerment is a key driver for action, which again leads us back to what you and your universities are doing.

On governance, we can appreciate how governance is obviously at the very center of any urban agenda. The HABITAT III process highlights the challenges of organizing governance and administration across fragmented metropolitan regions. Once again, I know you see where you fit into these discussions and actions because you are dealing the complexities of divided jurisdictions all the time.

On economic development, the complexity of the urban environment requires strategies which establish policies tailored to local conditions. Ultimately, success in economic development requires defining and strengthening "a full portfolio of instruments that enhances economic development while supporting a high quality of life." This is, of course, where you enter in as important catalysts for economic development.

The HABITAT III meetings ended last week with the United Nations and its member states ratifying an urban agenda around these themes. The United Nations and all its member states are now committed to an urban paradigm shift that will reshape the way we plan, finance, develop, govern and manage cities. How can all of us convert aspiration to reality?

Ultimately, the answer to only one question really matters: when parents ask if they want their children to live in this place at this time the answer is a resounding yes. The answer is more likely yes if the intellectual and developmental resources you all represent help make it so. It is only when we all embrace a holistic view of the city as a place of promise that we can move towards meeting the challenges posed by the UN just this week, and posed by parents all over the world all the time. That is what all of you will be discussing the next couple of days. 
In closing I want to return to the connection between the urban and the creative and make note of an article appearing in today's Washington Post entitled "Five Myths about Genius." Among the myths author Eric Weiner debunks is that geniuses can pop up anywhere at any time. He notes that there are "genius clusters." These are certain places at certain times that produce what he calls a "mother lode of brilliant minds and good ideas." He continues that "these places were, in some ways, quite different, but they also shared certain characteristics. For starters, almost all were cities. The density and intimacy of an urban setting nurture creativity. All of these places, too, possessed an outside degree of tolerance and 'openness to experience'."

There is nothing more important to such cities than great universities such as those represented here this evening. Thank you. 


\section{Author Information}

Blair A. Ruble

Vice President for Programs

Woodrow Wilson Center

E-mail: blair.ruble@wilsoncenter.org

Telephone: 202-691-4239 